\author{
Katarzyna PIETRUCHA-URBANIK ${ }^{1}$ \\ Adrian SZELIGOWSKI ${ }^{2}$
}

\title{
ANALYSIS OF WATER CONSUMPTION CHANGEABILITY IN THE EXEMPLARY WATER SYSTEM
}

\begin{abstract}
In the paper the analysis of changes in water consumption in the city of Krosno on the basis of the operating data from the last decade was presented. Moreover, the characteristics of Krosno and the water supply system were presented. Water production analysis depending on the month and season was shown. Unit average daily water consumption per capita was calculated. The analysis showed that the demand for water in Krosno is subjected to fluctuations. The highest water demand was recorded in July and August and the lowest in November. Water consumption in Krosno is steadily declined, in 2006 it amounted to $6397594 \mathrm{~m}^{3} /$ year, whereas in 2014 it was $5392777 \mathrm{~m}^{3} /$ year. Major contribution to the decrease in water consumption in Krosno has industry where over $30 \%$ of total water consumption fell to $15 \%$. Low water consumption is influenced by the high price of water, the use of local water supplies, as well as water saving. The calculated values were compared with the Regulation of the Infrastructure Minister concerning the average water consumption standards, corresponding to the fourth category of sanitary equipment. Krosno water supply network is continuously expanded and new connections are created so that more and more consumers have access to tap water (currently approx. 94\% use the water supply network).
\end{abstract}

Keywords: water consumption, water production, water consumption indicators, changeability in water consumption

\section{Introduction}

Krosno is a city located in the area of Jasło-Sanok, which is a border to the north of the Strzyżow-Dynów Foothills and on the south of the Beskid Niski. Krosno is located in an area with a temperate climate with frequent strong winds from the Dukla Pass. The city center is situated on a height of $277 \mathrm{~m}$ above sea level, on a hill, at the confluence of river and stream Wisłok Lubatówka [5].

\footnotetext{
${ }^{1}$ Autor do korespondencji/corresponding author: Katarzyna Pietrucha-Urbanik, Politechnika Rzeszowska, al. Powstańców Warszawy 6, 35-959 Rzeszów, tel. 17 8651703, kpiet@ prz.edu.pl

2 Adrian Szeligowski, Politechnika Rzeszowska
} 
Krosno covers an area of approx. $45 \mathrm{~km}^{2}$, with approx. 50 thousands inhabitants. According to data obtained from Central Statistical Office (CSO) for the last 10 years, the number of inhabitants in Krosno decreased by more than 600 people, whereas the number of people who inhabit the community directly adjacent to the city increased.

According to the data of the CSO in 2005 the number of residents of Krosno was the 47817 thousands. Apart from 2008 and 2009 when the population rose by a total of 86 , in the remaining years systematic decline from 40 to 250 people was recorded. At the end of 2014 the number of residents was 47140, which over the last decade decreased of about 677 people [2].

Currently Krosno water supply system provides water for industrial plants and residents in the area of Krosno and to ten municipalities of the district Krosno and Sanok (Besko, Zarszyn, Chorkówka, Jedlicze, Iwonicz, Korczyna, Wojaszówka, Rymanów, Krościenko Wyżne, Place Piastowe) [4, 5].

Despite supplying so many municipalities the length of water supply network in the city is almost two times longer than beyond the city. It shows a highly developed water supply system, a large number of connections and a high percentage of the population in Krosno using water from the network. Almost every water supply system has the greatest length of the distributional pipes, the same situation is in analysed area, which occupies $50 \%$ of the whole network. The shortest is the main network occupying only $14 \%$, the rest are connections with a total length of $230,9 \mathrm{~km}$ [7].

The largest increase in the length of the distribution network occurred in the years 2006 and 2007, up to $38,9 \mathrm{~km}$, what with a small number of new connections resulted in a decrease of over $20 \%$ of connections in comparison to pipes length. The reverse situation occurred in the years 2009 and 2010, where the majority of new connections in the analysed period were built, i.e. 1006 units.

\section{Production capacity and water consumption}

Currently, the city of Krosno and 10 communes of Krosno and Sanok are supplied from three Water Treatment Plants (WTPs) in Szczepańcowa, Iskrzynia and Sieniawa a production capacity of approx. $36000 \mathrm{~m}^{3} / \mathrm{d}$ and with the average daily production of approx. $14500 \mathrm{~m}^{3}$. The oldest plant is located in Szczepańcowa which supplies Krosno from water intake in the river Jasiołka, while the other two plants are located on the river Wisłok (Iskrzynia and Sieniawa) $[4,5]$. The largest production capacity has Water Treatment Plant in Sieniawa that could provide nearly $50 \%$ of the total water demand, not much less has plant in Iskrzynia $14,000 \mathrm{~m}^{3} / \mathrm{d}$, while the smallest plant is the oldest plant in Szczepańcowa.

Summary of the average daily water consumption and production is shown in Figure 1. 


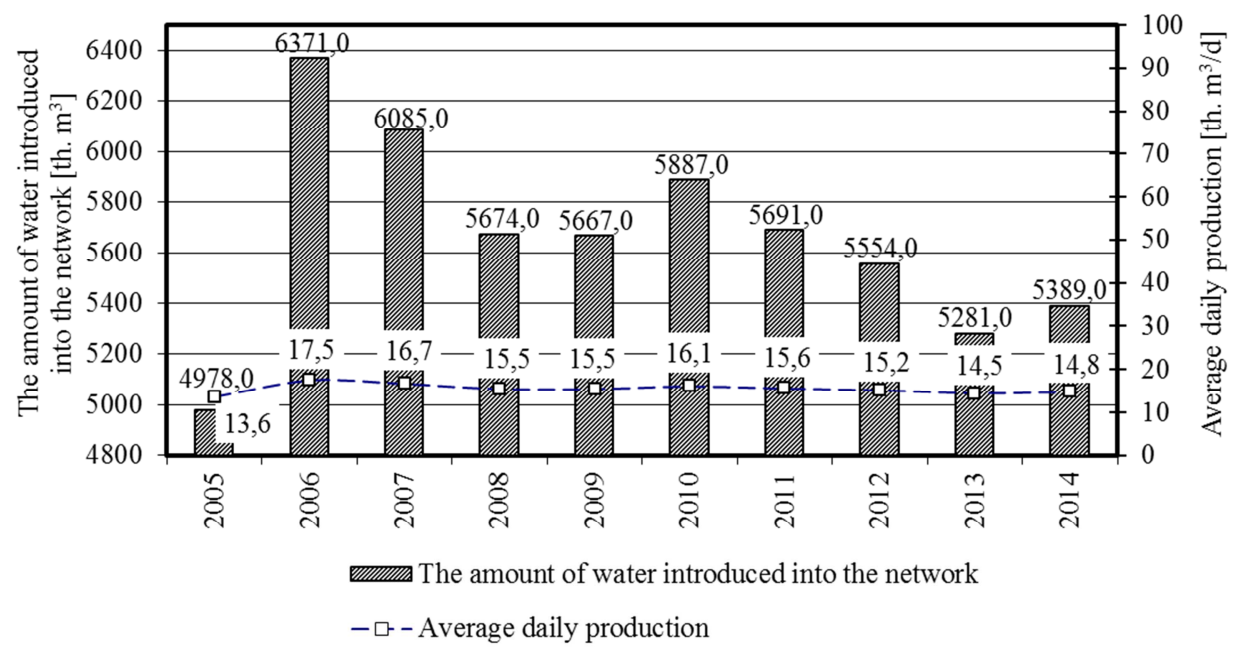

Fig. 1. Summary of water consumption and average daily water production Rys. 1. Zestawienie poboru i średniodobowej produkcji

Figure 2 shows water introduced from each WTP.

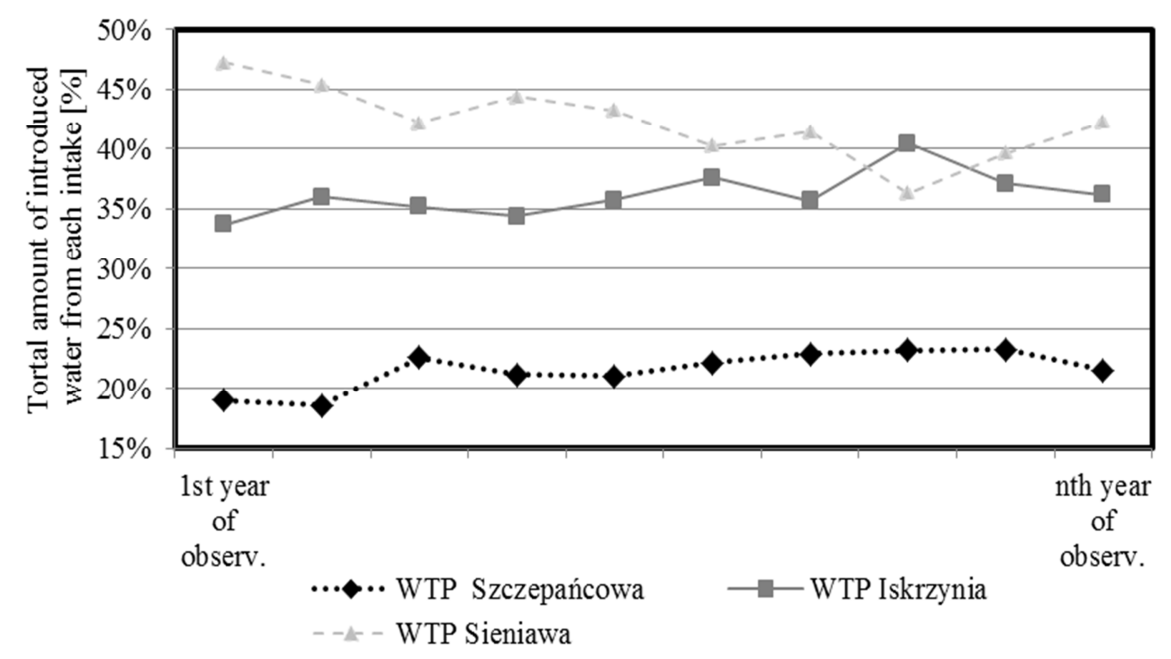

Fig. 2. Total amount of water introduced from WTPs: Szczepańcowa, Sieniawa and Iskrzynia Rys. 2. Łączna ilość wody wtłoczonej z ZUW: Szczepańcowej, Sieniawy oraz Iskrzyni

The percentage of water introduced into the water supply network over nine years is at the level $42,24 \%$ for WTP "Wisłok" Sieniawa, 36,21\% for WTP "Wisłok" Iskrzynia, 21,55\% WTP "Jasiołka" Szczepańcowa. WTP "Wisłok" Sieniawa produced the most amount of water. Only in 2013 WTP "Wisłok" Is- 
krzynia produced more water than WTP "Wisłok" Sieniawa by about 4,13\%. It was due to modernization of WTP "Wisłok" Sieniawa. Water production from plant "Jasiołka" Szczepańcowa between 2006 and the average increased by $2,52 \%$, between 2006 and 2014 increased by 4,25\%. The increase in production is due to the economic activities of the company, the production cost of $1 \mathrm{~m}^{3}$ of water in plant "Jasiołka" Szczepańcowa is the lowest among all the WTP [3].

According to the data obtained from the Municipal Enterprise for Communal Economy in Krosno the largest water production amounted to 6371 thousand $\mathrm{m}^{3}$ and occurred in 2006. The smallest amount of water was produced in 2005 and amounted to 4978 thousand $\mathrm{m}^{3}$, it differs by 1393 thousand $\mathrm{m}^{3}$ in comparison to 2006 . The range of the average daily water production in the analysed interval is from 13,6 to 17,5 th. $\mathrm{m}^{3} / \mathrm{d}$, which in comparison to production capacity of 3 plants with 36 th. $\mathrm{m}^{3} / \mathrm{d}$ gives the capacity utilization of approx. $38-49 \%$. The precise values of the capacity utilization in the water treatment plants in the reporting period are shown in Figure 3.

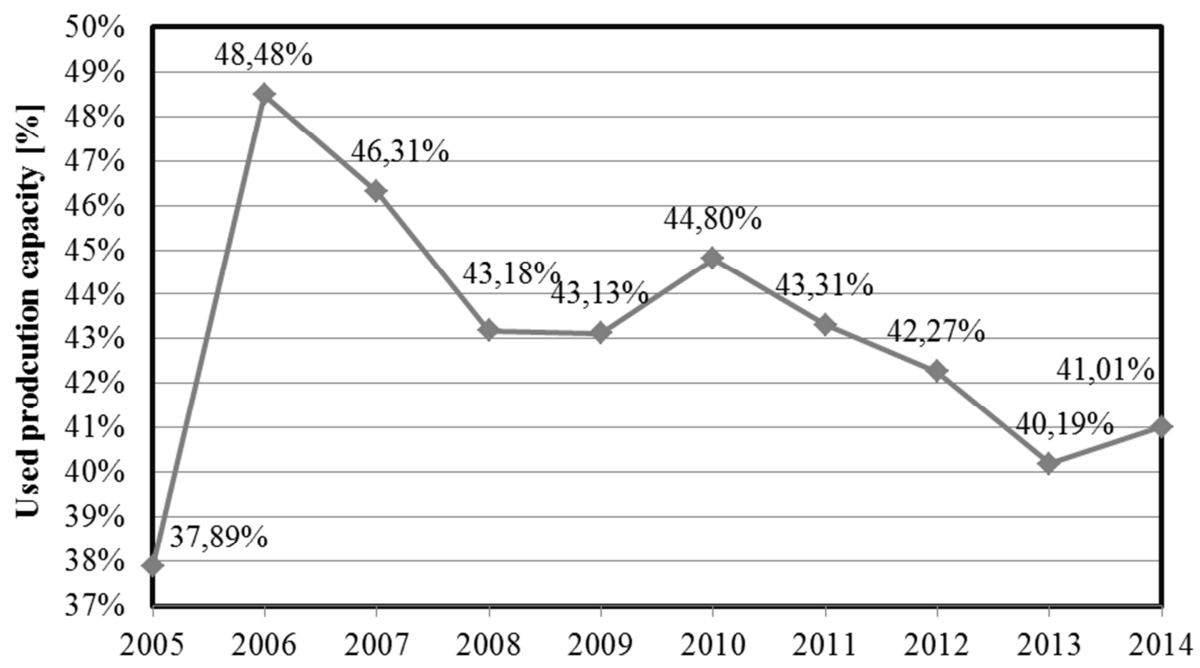

Fig. 3. The percentage of used production capacity

Rys. 3. Procent wykorzystywanej zdolności produkcyjnej

Monthly changeability of water consumption in housing is dependent on many different factors, e.g. vacations, residents lifestyle, their plans for holidays and weather conditions. In contrast, the water consumption in the industry is completely different. During the holiday season it is the lowest due to the decline in production and departures of employees, which also occurs in the holiday periods. 
The difference between the water production based on the arithmetic mean of the analysed years in individual months is not large and is less than $9 \%$. The month with the highest water consumption was March in 2006 when $570819 \mathrm{~m}^{3}$ of water was used and the lowest in February 2014 with the amount of $410621 \mathrm{~m}^{3}$, the difference is almost $30 \%$. The arithmetic means of the analysed period indicate that the month with the highest demand of water is July, which is the month in which the highest temperatures of the year were recorded (Fig. 4).

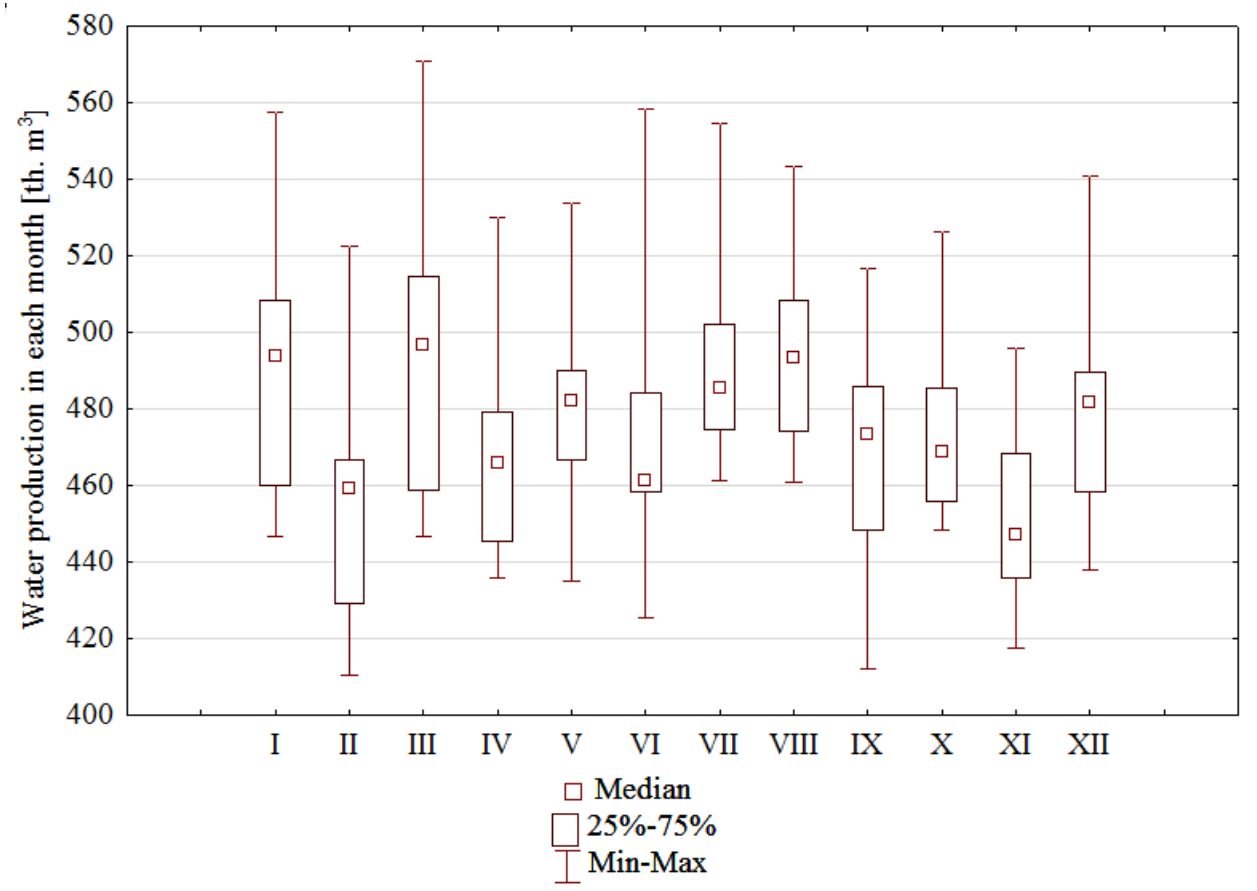

Fig. 4. Water production in each month [th. $\left.\mathrm{m}^{3}\right]$

Rys. 4. Produkcja wody w poszczególnych miesiącach [tys. $\mathrm{m}^{3}$ ]

Grouping water production for individual seasons shows how much water has been taken depending on temperatures. Taking into account the arithmetic average of the analysed years, water consumption in individual seasons remains at constant level. The highest water consumption occurred in summer, while in autumn and winter water consumption was lower than in other seasons and in spring of 2013 reached the lowest value of 1,296 thousand $\mathrm{m}^{3}$.

As to indicate the percentage value of changeability through seasonal indicator was calculated according to the formula [8]: 


$$
S_{i}=\frac{\bar{y}_{i} \cdot d}{\sum_{i=1}^{d_{j}} \bar{y}_{i}} \cdot 100
$$

where $S_{i}$ is seasonal indicator for subperiod; is arithmetic mean of the magnitude of the examined occurrence in uninominal subperiods (January, with February, $\ldots$, December) in years $2000 \div 2008[11] ; d_{j}$ is number of uninominal subperiods, $d_{j}=4$; $\mathrm{d}$ is number of months in the year, $d=12$.

Designated seasonal variations for each month is shown in Figure 5.

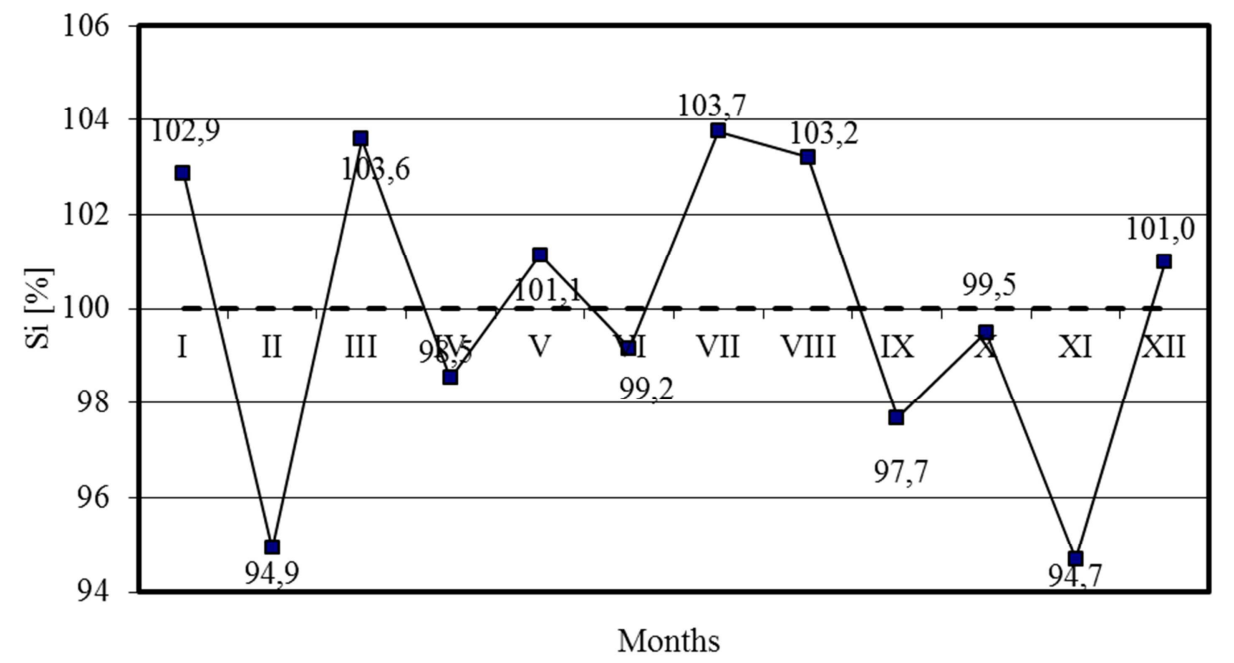

Fig. 5. Seasonal variations of the water consumption in distinguished months

Rys. 5. Wahania sezonowe zużycia wody w poszczególnych miesiącach

The highest water consumption compared to the average value occurred in July (on average 3,7\%), August (on average 3,2\%) and March (on average $3,6 \%$ ). Water consumption in the four months (April, May, June, October) shapes around the average value. The lowest consumption occurred in February, November which confirmed the previously conducted analysis.

In order to determine the average changeability rate in water consumption the chain indexes were designated, as shown in Table 1. 
Table 1. Chain changes in water consumption

Tabela 1. Łańcuchowe zmiany zużycia wody

\begin{tabular}{|c|c|c|c|c|c|c|c|c|c|c|c|c|c|c|c|}
\hline$\stackrel{\grave{\Xi}}{\grave{\nu}}$ & 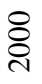 & $\underset{\check{্}}{\bar{\delta}}$ & ઠิ & $\underset{\text { }}{\tilde{i}}$ & $\underset{d}{\stackrel{d}{0}}$ & 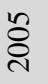 & $\underset{\sim}{\stackrel{্}{~}}$ & ¿্ণ & 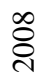 & ஜे & $\stackrel{\circ}{\stackrel{2}{ }}$ & $\overline{\vec{i}}$ & 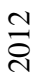 & $\stackrel{m}{\stackrel{\sim}{*}}$ & $\underset{⿱ 亠}{\stackrel{\Xi}{*}}$ \\
\hline.$\Xi$ & 1 & $\begin{array}{l}0 \\
\infty \\
\infty \\
0 \\
0\end{array}$ & $\overline{8}$ & $\begin{array}{l}2 \\
\stackrel{0}{0} \\
0\end{array}$ & $\vec{J}$ & گ̆ & $\begin{array}{c}\hat{\infty} \\
\infty \\
0\end{array}$ & 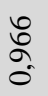 & $\hat{\circ}$ & $\begin{array}{c}\frac{+}{\infty} \\
0 \\
0\end{array}$ & $\begin{array}{l}\hat{\sigma} \\
\hat{\sigma}\end{array}$ & $\begin{array}{l}\text { ஜ̊ } \\
\stackrel{0}{0}\end{array}$ & $\underset{\sim}{\nexists}$ & $\frac{a}{\frac{\pi}{0}}$ & $\begin{array}{l}\hat{n} \\
\hat{\sigma}\end{array}$ \\
\hline
\end{tabular}

Then the geometric average of the chain index chain was determined according to the formula [6]:

$$
i_{t / t-1}=\sqrt[n-1]{i_{2 / 1} \cdot i_{3 / 2} \cdot \ldots \cdot \frac{i_{n}}{n}-1}
$$

and the average rate of change was calculated according to the formula [6]:

$$
\bar{T}=\left(i_{t / t-1}-1\right) \cdot 100 \%
$$

Based on the calculations the average rate of change amounted to $-4,31 \%$, which means that the annual water consumption decreased on average of about $4,31 \%$.

The amount of water consumed by three basic groups of recipients was shown in the Fig. 6. The largest decrease in water consumption was observed in a group of industrial customers, with almost 1000 thousand. $\mathrm{m}^{3}$ to the level of 383 thousand. $\mathrm{m}^{3}$ in the last analysed year. Water consumption in households for the first five years of analysis decreased by 300 thousand. $\mathrm{m}^{3}$ and for the other years remained at constant level, while water consumption for other purposes is steadily declining, with the exception of 2012, in which water consumption was almost two times higher than in other years. The largest percentage of the total water consumption used for the purposes of households is $35-54 \%$. Despite the overall decline in water consumption the amount of water consumed for other purposes remained constant at about 30-35\%.

Detailed analysis of water consumption in the normal working week in the considered years of observation showed that the biggest water consumption occurred on Saturday and Wednesday, in the remaining days it remained at constant level. on average $40 \%$ higher water consumption compared eg. to Friday. Daily variation coefficient ranged from 1,16 to 1,54 . In the case of the day with the lowest water consumption, small fluctuations in water consumption occurred. These values do not differ from the data presented in the literature publications $[1,3,9,10]$.

In the Figure 7 the total consumption of water, in industry, households and for other purposes, per statistical inhabitant was shown. 


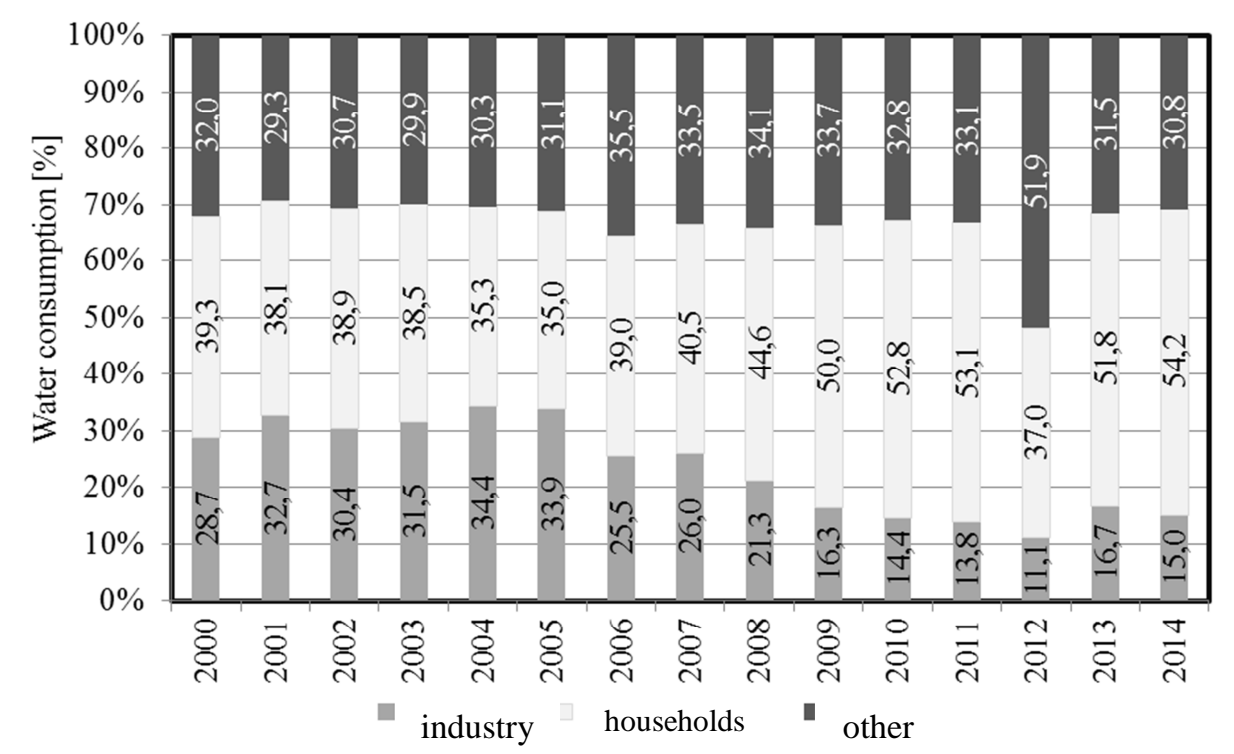

Fig. 6. Percentage of water consumption in individual groups of recipients

Rys. 6. Procentowy udział zużycia wody w poszczególnych grupach odbiorców

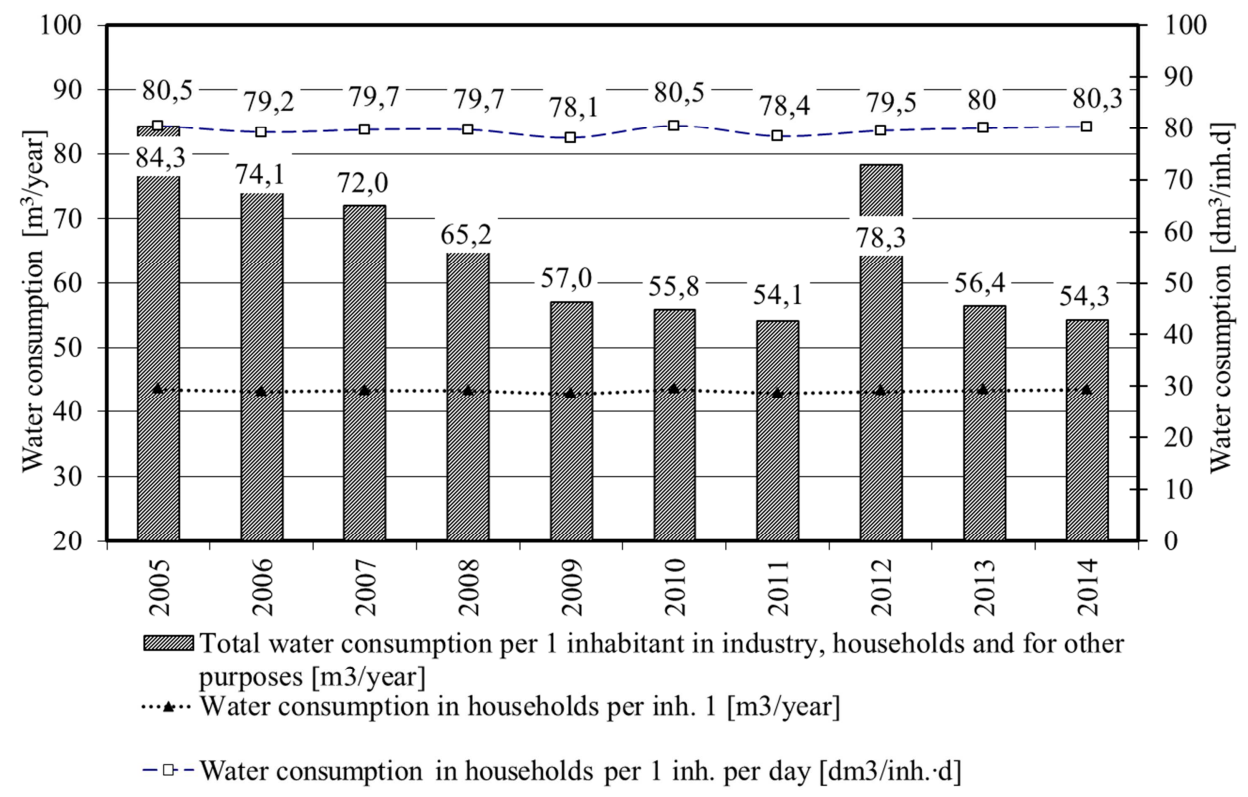

Fig. 7. Water consumption per 1 inhabitant

Rys. 7. Zużycie wody na 1 mieszkańca 
Water consumption in the analysed period of time remained constant at approx. $29 \mathrm{~m}^{3}$ per year or about $80 \mathrm{dm}^{3} / \mathrm{Md}$. Taking into account also other purposes, water consumption per capita has decreased significantly which was caused primarily by large decline of water consumption for industrial purposes.

\section{Conclusion}

Analysing water consumption by different groups of recipients it can be concluded that water consumption is decreasing mainly due to the increase of environmental awareness, rational water use, more modern and less water consuming household appliances, upgraded sanitary fittings, reducing water losses (due to seal installation). The most important reason, however, remains the collapse of industry in the $90 \mathrm{~s}$, in particular the industry using the most water. Companies also modernize their production through the introduction of closed circuit. In the vast majority of agriculture and forestry own water intakes are used.

Conducting detailed analysis for water production and consumption for each unit of the settlement has a big impact on the proper operation of the water supply system. It also allows making the right decisions on the renovation or modernization of the network and thereby allows the greatest reliability in its functioning.

\section{Literature}

[1] Dymaczewski Z., Sozański M.M. Wodociągi i kanalizacja w Polsce tradycja i współczesność, Polska Fundacja Ochrony Zasobów Wodnych, Poznań-Bydgoszcz 2002.

[2] Główny Urząd Statystyczny, Ochrona środowiska, Roczniki statystyczne za lata 1995-2014.

[3] Heidrich Z., Jędrzejkiewicz J.: Analiza zużycia wody w miastach polskich w latach 1995-2005. Ochrona Środowiska 2007, vol. 29, nr 4. s. 29-34.

[4] http://www.bip.umkrosno.pl/?c=mdTresc-cmPokaz-74 [dostęp: 06.01.2016].

[5] http://www.ekrosno.pl/holding/mpgk/zaklad_wodociagow_i_kanalizacji/ [dostęp: 18.12.2015].

[6] Jóźwiak J., Podgórski J.: Statystyka od podstaw, Polskie Wydawnictwo Ekonomiczne, Warszawa 2012.

[7] Rak J.: Metoda planowania remontów sieci wodociągowej na przykładzie miasta Krosna. Czasopismo Inżynierii Lądowej, Środowiska i Architektury, JCEEA, z. 61 (1/14), 2014, s. 225-232. DOI:10.7862/rb.2014.15.

[8] Sobczyk M. Statystyka. Wydawnictwo PWN. Warszawa, 1996.

[9] Studziński A., Pietrucha-Urbanik K., Dąbek M.: Analiza zużycia wody w miejscowości Stalowa Wola. Czasopismo Inżynierii Lądowej, Środowiska i Architektury, JCEEA, z. 61 (1/14), 2014, s. 323-332. DOI:10.7862/rb.2014.22. 
[10] Studziński A., Pietrucha-Urbanik K., Mędrala A.: Analiza strat wody oraz awaryjności w wybranych systemach zaopatrzenia w wodę, Czasopismo Inżynierii Lądowej, Środowiska i Architektury, JCEEA, z. 61 (4/14), 2014, s. 193-201. DOI:10.7862/rb.2014.144.

[11] Tchórzewska-Cieślak B., Pietrucha K.: The analysis of the exploitation of the water network on the example of the Krosno water network [w:] Zaopatrzenie w wodę, jakość i ochrona wód - zagadnienia współczesne "Water Supply and Water Quality" - present issues", Polskie Zrzeszenie Inżynierów i Techników Sanitarnych O/ Wielkopolski, 2010,II, 119-128.

\section{ANALIZA ZMIENNOŚCI ZUŻYCIA WODY W PRZYKŁADOWYM SYSTEMIE WODOCIĄGOWYM}

\section{Streszczen ie}

W pracy przedstawiono analizę zużycia wody oraz zmian poboru wody w mieście Krosno na podstawie uzyskanych danych eksploatacyjnych. Ponadto przedstawiono charakterystykę miasta Krosno oraz systemu wodociągowego. Przedstawiono produkcję wody w zależności od miesiąca i pory roku. Wyznaczono jednostkowe średniodobowe zużycie wody na jednego mieszkańca. Analiza wykazała, że zapotrzebowanie na wodę w Krośnie podlega wahaniom i jest nierównomierne. Najwyższe zapotrzebowanie na wodę odnotowano w lipcu i sierpniu, a najmniejsze w listopadzie. Zużycie wody w Krośnie od dziesięciu lat systematycznie spada, w 2006 roku wtłoczono $6397594 \mathrm{~m}^{3} /$ rok natomiast w 2014 roku - $5392777 \mathrm{~m}^{3} /$ rok. Główny udział w spadku zużycia wody w Krośnie miał przemysł, który z ponad 30\% ogólnego zużycia wody spadł do $15 \%$. Na niskie zużycie wody wpływa wysoka cena wody, korzystanie z lokalnych ujęć wody, jak również oszczędzanie wody. Wyznaczone wartości zostały porównane z Rozporządzeniem Ministra Infrastruktury dotyczącego przeciętnych norm zużycia wody, co odpowiada czwartej kategorii wyposażenia sanitarnego. Krośnieńska sieć wodociągowa jest stale rozbudowywana i powstają nowe przyłącza, dzięki czemu coraz więcej odbiorców ma dostęp do wodociągowej wody (obecnie ok. 94\% korzystających z sieci wodociągowej).

Słowa kluczowe: zużycie wody, produkcja wody, wskaźniki zużycia wody, zmienność zużycia wody

Przestano do redakcji: 29.01.2016 $r$.

Przyjęto do druku: 1.06.2016 r.

DOI: $10.7862 /$ rb.2016.125 